\title{
MODEL PEMBELAJARAN DISCOVERY LEARNING UNTUK MENINGKATKAN HASIL BELAJAR PESERTA DIDIK MATA PELAJARAN AKUNTANSI
}

\author{
Oleh: Budi Mulyati ${ }^{1)}$, Idmi $^{2)}$, Siti Arfiyanah ${ }^{3)}$ \\ Universitas Banten Jaya \\ Serang, Indonesia \\ budimulyati@unbaja.ac.id ${ }^{1)}$, arfiyanah95@gmail.com ${ }^{2)}$,idmibaja@gmail.com ${ }^{3)}$
}

\begin{abstract}
This research was aimed to improve the accounting learning result using Discovery Learning Model for student in class XI SMK Al- Insan Cilegon. This research used class room action research method with two cycles. Each cycle had four steps: planning, action, observing and reflection. The research subject were 45 students and the teacher as the collaborator team.The research results showed that discovery learning model could improve the student learning achievement because, at first cycle, from 45 students, almost 66.7\% (30 students) could achieve the minimum score and at the second cycle all student achieved the minimum score.
\end{abstract}

Keywords: Discovery learning model, student result.

\section{PENDAHULUAN}

Kegiatan yang melibatkan interaksi guru dan peserta didik harus berjalan secara terencana. Perencanaan ini perlu dilakukan oleh guru sebelum proses pembelajaran dimulai. Dengan adanya perencanaan yang baik, maka guru akan dapat menentukan tentang hal- hal apa saja yang harus dilakukan selama proses pembelajaran berlangsung. Sehingga guru dan peserta didik dapat mencapai tujuan pembelajaran yang telah ditetapkan sebelumnya.

Proses pembelajaran yang berlangsung di kelas tidak terlepas dari bagaimana guru melakukan komunikasi dengan peserta didik. Komunikasi yang dilakukan oleh guru tidak sekedar dalam hal penyampaian materi, namun komunikasi yang juga memberikan motivasi kepada peserta didik. Pemberian motivasi kepada peserta didik akan berdampak pada peningkatan tingkat kepercayaan diri peserta didik terhadap kemampuannya dalam belajar. Lebih jauh lagi bahwa, motivasi yang diberikan guru akan menjadi motivasi bagi diri peserta didik. Sehingga setiap tahapan dalam proses pembelajaran yang dilalui peserta didik dapat dimaknai dengan baik. Peserta didik akan belajar karena keinginan dan motivasinya sendiri. Dengan demikian, peserta didik akan menjadi lebih terbuka terhadap segala beban belajar yang harus dilaluinya. Peserta didik akan menerima itu sebagai kebutuhannya. Hal tersebut 
akan memudahkan guru untuk memberika pengalaman belajar kepada peserta didik, sehingga tujuan pembelajaran dapat tercapai.

Motivasi belajar merupakan hal yang sangat penting dimiliki oleh Peserta Didik. Menurut Abin Syamsuddin Makmun (dalam Sudrajat, 2008) dijelaskan bahwa untuk memahami motivasi seorang individu dapat dilihat dari beberapa indikator, diantaranya (1) durasi kegiatan, (2) frekuensi kegiatan, (3) persistensi pada kegiatan, (4) ketabahan, (5) pengorbanan untuk mencapai tujuan, (6) tingkat aspirasi, (7) tingkat kualifikasi prestasi atau produk (output) yang dicapai dari kegiatan yang dilakukan, dan (8) arah sikap terhadap sasaran kegiatan. Dengan mengetahui teori ini maka diharapkan guru dapat memahami tentang persiapan apa saja yang harus dilakukan untuk di berikan guru di kelas. Karena dengan adanya motivasi yang tinggi, maka kendala atau hambatan yang ditemui saat proses pembelajaran akan relatif mudah tertangani.

Guru sebagai bagian dari subjek dalam sistem pendidikan memiliki peran yang sangat penting di sekolah. Pendidikan di sekolah tidak bisa lepas dari kegiatan belajar mengajar yang meliputi seluruh aktivitas yang menyangkut pemberian materi pelajaran yang dilakukan oleh guru agar Peserta Didik memperoleh pengetahuan yang bermanfaat bagi kehidupan.

Guru memerlukan proses yang lama untuk meningkatkan prestasi belajar Peserta Didik. Berbagai hambatan sering ditemui oleh guru dan peserta didik dalam prosesnya. Bagi Peserta Didik sendiri, kendala meraih prestasi belajar ini sulit untuk diungkapkan. Peserta Didik mengalami kesulitan untuk mengenali apa dan bagaimana kesulitan belajar yang sedang dialaminya, Peserta Didik umumnya baru menyadari tentang hamabatan yang dialaminya pada saat akhir proses belajar, bahwa ternyata prestasi belajarnya tidak berkembang.

Untuk mendukung peningkatan kualitas pendidikan, ada banyak faktor yang harus diperhatikan. Kita tidak hanya melihat dari prestasi akademik yang dapat dicapai masing-masing Peserta Didik, tapi juga dapat dilihat dari kualitas pengelola baik secara langsung maupun yang tidak terlibat secara langsung. Hal ini membuktikan bahwa pendidikan merupakan satu jalinan sistem yang tidak dapat mengabaikan komponen yang terkait di dalamnya atau menganggap suatu posisi atau suatu komponen lebih penting dari pada komponen yang lain.

Berdasarkan hasil kegiatan observasi yang peneliti telah lakukan di 
SMK Al- Insan, menunjukan bahwa hasil belajar peserta didik yang berada di jurusan akuntansi masih belum memenuhi nilai minimal KKM sebesr 75. Dari 45 peserta didik hanya terdapat 6 peserta didik yang memenuhi syarat nilai minimal. Setelah peneliti melakukan analisis, peneliti mengasusmikan bahwa hal ini disebabkan karena kondisi pembelajaran mata pelajaran akuntansi di SMK AlInsan masih bersifat text book/ atau berpusat pada buku yang dimiliki oleh guru. Berdasarkan kondisi yang demikian, maka proses pembelajaran yang terjadi hanya berpusat pada guru. Guru yang menentukan tentang materi apa yang harus dipelajari peserta didik. Proses ini dapat pula diisi dengan kegiatan tanya jawab dan pemberian latihan soal atau tugas. Namun terbatas pada materi yang diberikan guru. Dapat dikatakan bahwa penggunaan metode ini merupakan metode pembelajaran yang dominan dengan kegiatan ceramah guru.

Dengan menggunakan model pembelajaran Discovery Learning peserta didik diharapkan lebih termotivasi untuk meningkatkan hasil belajar dan lebih berpartisipasi aktif dalam proses pembelajaran. Semangat kerja sama antar anggota kelompok juga dapat ditingkatkan. Dengan adanya partisipasi aktif peserta didik, maka guru akan dituntut untuk dapat membuat situasi yang memungkinkan peserta didik dapat menemukan pengetahuannya sendiri.

Model pembelajaran Discovery adalah model pembelajaran yang mengupayakan proses pemerolehan pengetahuan bagi peserta didik yang diupayakan oleh peserta didik itu sendiri. Dalam model pembelajaran ini, guru membimbing aktivitas yang mengutamakan pada adanya penemuan konsep dan prinsip suatu materi oleh peserta didik. Peran guru dalam model pembelajaran ini adalah sebagai pembimbing yang memberikan kebebasan kepada peserta didik untuk belajar secara aktif. Guru tidak memberikan materi selayaknya seperti yang umum ditemukan dalam metode ceramah, namun memberikan kesempatan kepada peserta didik untuk mengumpulkan pengetahuan dan informasinya sendiri dari mulai awal, hingga akhir. Pada akhirnya peserta didik memiliki kesimpulannya sendiri tentang materi yang sedang dipelajarinya.

Terdapat beberapa kelebihan digunakannya model pembelajaran discovery ini yakni: 1) penyajian materi disarikan dari pengalaman peserta didik sehari- hari, 2) peserta didik dapat mengambil contoh dari pengalaman mereka sehari- hari, 3) peserta didik belajar untuk dapat memecahkan 
masalahnya sendiri, sehingga peserta didik terbiasa untuk berpikir solutif, 4) peserta didik dapat menerima materi dengan lebih cepat karena contoh yang mereka gunakan merupakan contoh yang sering mereka temui dalam kehidupan sehari- hari, 5) peserta didik terlibat langsung dalam proses pembelajarannya.

Dari beberapa kelebihan discovery learning, terdapat beberapa kelemahannya, diantaranya: 1) model discovery sulit diterapkan untuk kelas dengan jumah peserta didik yang banyak, 2) bagi guru dan peserta didik yang terbiasa menggunakan cara lama, maka akan kesulitan untuk menerapkan model ini, karena model ini menuntut peserta didik untuk terlibat langsung, padahal pada model lama, peserta didik hanya diam menerima apa yang diberikan oleh guru.

Pembelajaran discovery learning yang diterapkan di SMK Al-Insan diharapkan dapat meningkatkan hasil belajar peserta didik dan partisipasi aktif peserta didik saat proses belajar mengajar berlangsung serta melatih peserta didik dalam menyelesaikan setiap persoalan atau kasus yang diberikan sehingga pada akhirnya akan tercapai hasil belajar yang maksimal. Peserta didik yang memiliki motivasi berprestasi tinggi dan partisipasi aktif dalam proses belajar mengajar akan lebih berprestasi bila dibandingkan dengan peserta didik yang kurang atau tidak mempunyai motivasi berprestasi tinggi dan berpartisipasi aktif dalam proses pembelajaran.

\section{METODE PENELITIAN}

Tempat penelitian berlokasi di Sekolah Menengah Kejuruan/ SMK ALINSAN jurusan Akuntansi kelas XI, penelitian ini dilakukan pada bulan April sampai Mei 2017.

Penelitian ini menggunakan penelitian tindakan kelas (Classroom Action Research). Tahap- tahap penelitian tindakan kelas yaitu :
a. Perencanaan (Planning)
b. Pelaksaan (Acting)
c. Observasi (Observasing)
d. Refleksi (Reflecting)

Pengumpulan data dalam penelitian ini menggunakan metode:

a. Observasi

Aspek yang diamati pada saat pembelajaran berlangsung yaitu hasil belajar peserta didik, keaktifan peserta didik dalam proses pembelajaran dan keaktifan peserta didik dalam mengajukan pertanyaan yang berkaitan dengan materi. Instrumen pengambilan datanya menggunakan lembar observasi.

b. Wawancara

Kegiatan ini dilakukan untuk mengetahui informasi mengenai kesulitan 
dan hambatan dalam proses pembelajaran serta tanggapan peserta didik tentang model pembelajaran yang digunakan. Untuk mendukung kegiatan ini, maka peneliti membuat pedoman wawancara untuk memudahkan proses penggalian informasinya.

c. Tes

Dalam penelitian ini peneliti menggunakan lembar tes buatan guru. Dengan teknik ini peneliti akan menskor tiap-tiap jawaban pada soal tes tersebut.

Tolok ukur untuk menilai keberhasilan penelitian ini adalah sebagai berikut:

a. Setelah menggunakan model pembelajaran kooperatif tipe Discovery Learning hasil belajar Peserta Didik akan mencapai presentase Ketuntasan Belajar $100 \%$ dari jumlah Peserta Didik 45 orang yang mencapai nilai KBM.

b. Aktivitas Peserta Didik dalam proses pembelajaran minimal sesuai standar dari jumlah peserta didik 45 orang, berada pada kriteria baik.

Adapun pengolahan data dalam penelitian ini yakni menggunakan teknik analisis data deskriptif. Data yang akan dianalisis diantaranya tes hasil belajar, serta hasil lembar observasi aktifitas peserta didik.
Dalam penelitian ini peneliti berkolaborasi dengan guru:

1. Guru sebagai pelaksana untuk malakukan penggunaan model pembelajaran kooperatif tipe Discovery Learning pada mata pelajaran akuntansi dengan konsep penggunaan kelompok Peserta Didik untuk berkerjasama dalam memaksimalkan kondisi belajar.

2. Peneliti berperan sebagai kolaborator dengan guru dan bersama-sama untuk menyusun rencana pelaksanaan pembelajaran, selain itu peneliti bertindak sebagai observer dan melakukan refleksi.

\section{HASIL PENELITIAN DAN} PEMBAHASAN

Siklus 1

\section{Perencanaan}

Pada perencanaan tindakan siklus 1 peneliti mempersiapkan perangkat mengajar dengan membuat rencana pelaksanaan pembelajaran menggunakan model Discovery Learning pada mata pelajaran Akuntansi Perusahan Jasa dan Dagang sebagai model yang akan di gunakan pada peroses pembelajaran di kelas XI Akuntansi. Kemudian di sepakati bahwa pelaksanaan tindakan pada siklus 1 akan di laksanakan selama 2 kali 
peretemuan yakni pada tanggal 26 April sampai 03 Mei 2017.

\section{Pelaksanaan}

Pelaksanaan tindakan 1 dilakukan selama 2 kali pertemuan, seperti yang sudah direncanakan, yaitu pada tanggal 26 April sampai 03 Mei 2017 di ruang XI Akuntansi sesuai dengan rencana pembelajaran yang tertulis di RPP.

Pada awal pelaksanaan tindakan diberikan suatu pengarahan tentang model pembelajaran kooperatif tipe Discovery Learning kepada Peserta Didik. Secara ringkas berikut ini adalah skenario pembelajaran pada pertemuan pertama di siklus 1:

1. Guru memberi salam kepada Peserta Didik dan berdo’a bersama-sama

2. Guru yang mengkondinisikan suasana belajar yang menyenangkan dengan model pembelajaran discovery learning

3. Guru menjelaskann tujuan pembelajaran atau kompetensi dasar yang akan dicapai

4. Guru menyampaikan cakupan materi pembelajaran untuk pertemuan pertama tentang perusahaan dagang

5. Guru menjelaskan aktifitas pembelajaran Peserta Didik dengan menerapkan pembelajaran Discovery Learning .
6. guru meminta Peserta Didik untuk mencatat dan mengklarifikasi lingkup dan teknik penilaian yang akan digunakan oleh guru( sikap, pengetahuan, dan keterampilan).

7. peserta didik dibagi menjadi beberapa kelompok, tiap kelompok terdiri dari 5-6 orang.

8. Menciptakan stimulus/ rangsangan pertanyaan.

a. Peserta didik mengamati materi perusahaan dagang melalui buku akuntansi/sumber lain

b. Peserta didik diminta untuk mencatat hasil pencarian mengenai perusahaan dagang

9. Menyiapkan Pernyataan Masalah(Problem Statemen)

a. Peserta didik mengajukan sejumlah pertanyaan hasil pengamatannya terkait dengan perusahaan dagang

b. Guru ikut mengarahkan atau membimbing peserta didik agar pertanyaan yang diajukan tidak keluar dari tujuan pembelajaran

10. Pengumpulan data ( Data Collecting)

a. Setiap kelompok Peserta Didik mengerjakan tugas dari guru untuk mencari pengetahuan tentang: pengertian, dan ciri-ciri perusahaan dagang dengan membaca buku/ mencari dari sumber lain, guru berkeliling ke setiap kelompok 
untuk membantu Peserta Didik yang kesulitan.

b. Peserta didik berdiskusi mengumpulkan informasi/ data untuk menjawab pertanyaan yang telah dirumuskan dalam lembar kerja yang diberikan.

\section{Mengolah Data (Data Processing)}

a. Peserta didik diminta menganalisis pengertian perusahaan dagang dan mengelompokan jenis-jenis perusahaan dagang

b. Peserta didik diminta mendiskusikan didalam kelompok untuk mengambil kesimpulan dari jawaban yang telah dirumuskan

c. Peserta didik merumuskan hasil analisisnya menjadi suatu ringkasan atau kesimpulan.

12. Menguji hasil (Verification dan Menyimpulkan).

Peserta didik menyampaikan hasil pengolahan dan asosiasi datanya didepan kelas

Skenario pada pertemuan kedua di siklus pertama sebagai berikut:

1. Guru memberi salam kepada Peserta Didik dan berdo'a bersama-sama

2. Guru menjelaskann tujuan pembelajaran atau kompetensi dasar yang akan dicapai
3. Guru menyampaikan cakupan materi pembelajaran untuk pertemuan kedua tentang mengerjakan soal-soal perusahaan dagang

4. Guru meminta Peserta Didik untuk mencatat dan mengklarifikasi lingkup dan teknik penilaian yang akan digunakan oleh guru ( sikap, pengetahuan, dan keterampilan).

5. Menciptakan stimulus/rangsangan pertanyaan

a. Guru menanyakan/mengingatkan kembali materi sebelumnya

b. Guru menyampaikan kegiatan hari ini

6. Menyiapkan Pernyataan Masalah

a. Peserta didik mengajukan sejumlah pertanyaan hasil pengamatannya terkait dengan perusahaan dagang

b. Guru ikut mengarahkan atau membimbing peserta didik agar pertanyaan yang diajukan tidak keluar dari tujuan pembelajaran

7. Pengumpulan data ( Data Collecting)

a. Setiap Peserta Didik mengerjakan tugas dari guru tentang perusahaan dagang

b. Peserta didik menjawab pertanyaan yang telah dirumuskan dalam lembar kerja yang diberikan.

8. Mengolah Data (Data Processing)

a. Peserta didik diminta mengerjakan soal perusahaan dagang 
b. Peserta didik diminta untuk mengambil kesimpulan dari jawaban yang telah dirumuskan.

9. Menguji hasil (Verification dan Menyimpulkan) Peserta didik menyampaikan hasil pengolahan dan asosiasi datanya didepan teman-teman

10. Guru bersama peneliti meminta lembar jawaban Peserta Didik

11. Guru dan peneliti menghitung jumlah soal yang benar

12. Guru membuat kesimpulan dari materi dan soal yang telah dikerjakan serta meriview pelaksanaan pembelajaran.

13. Guru memberi pengumuman tentang hasil soal

14. Menutup pembelajaran dengan berdo’a sesuai dengan agama dan keyakinan masing-masing.

\section{Observasi dan Evaluasi}

Observasi dilakukan oleh peneliti, mengacu pada lembar observasi yang telah disusun. Observasi ini dilakukan untuk mengevaluasi penerapan model pembelajaran kooperatif tipe Discovery Learning dan untuk mengetahui kemampuan Peserta Didik menerima materi pembelajaran dengan adanya model pembelajaran kooperatif tipe Discovery Learning. Peneliti melakukan penialaian terhadap Peserta Didik selama kegiatan pembelajaran, yang meliputi kemampuan bekerjasama dalam belajar kelompok dan kerja kelompok, kemampuan bertanya atau mengeluarkan pedapat dan kemampuan menjawab pertanyaan.

Pada pertemuan pertama, Peserta Didik terlihat antusias ketika pelaksanaan belajar dan kerja kelompok, Peserta Didik belajar bersama kelompoknya tentang materi perusahaan dagang dengan baik, meskipun masih ada beberapa Peserta Didik yang belum bisa menyesuaikan diri dengan anggota kelompoknya. Suasana belajar tampak aktif dengan adanya interaksi antar anggota kelompok. Pada pertemuan kedua semua Peserta Didik mengerjakan soal tes dengan baik dan mandiri.

\section{Analisis dan Refleksi}

Sebelum diterapkan model pembelajaran Discovery Learning nilai yang mencapai nilai KBM hanya 6 Peserta Didik, namun setelah diterapkan model ini, nilai Peserta Didik yang mendapat nilai KBM sebanyak 30 Peserta Didik. Jumlah Peserta Didik yang mendapatkan nilai ketuntasan Belajar Minimal adalah 30 Peserta Didik dari jumlah keseluruhan 45 Peserta Didik. Dengan kata lain, indikator keberhasilan pada siklus 1 mencapai $66,7 \%$ yang mencapai nilai ketuntasan belajar.

Setelah dilakukan perencanaan, tindakan, dan pengamatan pada siklus 1 peneliti mengadakan refleksi tindakan yang akan direncanakan pada siklus II. 
Pada pelaksanaan siklus II direncanakan satu kali pertemuan, tanggal 06 mei 2017

\section{Siklus II}

\section{Perencanaan}

Pada pelaksanaa tindakan pada siklus II peneliti memperbaiki kekurangan yang terjadi pada siklus 1, adapun kelemahan dan kelebihan yang terjadi pada siklus 1 diharapkan dapat mengalami peningkatan pada siklus II pada tahap ini, peneliti merencanakan rancangan tindakan yang akan dilaksanakan pada tanggal 06 mei 2017.

\section{Pelaksanaan Tindakan}

Pada siklus II ini dilakukan pada tanggal 06 Mei 2017. Secara ringkas berikut ini skenario penerapan model pembelajaran Discovery Learning:

1. Guru memberi salam kepada Peserta Didik dan berdo'a bersama-sama

2. Guru menjelaskann tujuan pembelajaran atau kompetensi dasar yang akan dicapai

3. Guru menyampaikan cakupan materi pembelajaran untuk pertemuan pertama tentang mengerjakan soal-soal pencatatan transaksi perusahaan dagang

4. guru meminta Peserta Didik untuk mencatat dan mengklarifikasi lingkup dan teknik penilaian yang akan digunakan oleh guru( sikap, pengetahuan, dan keterampilan).
5. Menciptakan stimulus/rangsangan pertanyaan

6. Guru menanyakan/mengingatkan kembali materi sebelumnya

7. Guru menyampaikan kegiatan hari ini

8. Menyiapkan Pernyataan Masalah

a. Peserta didik mengajukan sejumlah pertanyaan hasil pengamatannya terkait dengan pencatatan transaksi perusahaan dagang, dan

b. Guru ikut mengarahkan atau membimbing peserta didik agar pertanyaan yang diajukan tidak keluar dari tujuan pembelajaran

9. Pengumpulan data ( Data Collecting)

a. Setiap peserta didik mengerjakan tugas dari guru tentang pencatatan transaksi keuangan perusahaan dagang

b. Peserta didik menjawab pertanyaan yang telah dirumuskan dalam lembar kerja yang diberikan.

10. Mengolah Data (Data Processing)

a. Peserta didik diminta mengerjakan soal praktek pencatatan perusahaan dagang

b. Peserta didik diminta untuk mengambil kesimpulan dari jawaban yang telah dirumuskan.

11. Menguji hasil

Peserta didik menyampaikan hasil pengolahan dan asosiasi datanya didepan teman-teman. 
12. Guru bersama peneliti meminta lembar jawaban Peserta didik

13. Guru dan peneliti menghitung jumlah soal yang benar

14. Guru membuat kesimpulan dari materi dan soal yang telah dikerjakan serta melakukan review terhadap hasil pelaksanaan pembelajaran.

15. Guru memberi pengumuman tentang hasil belajar peserta didik.

16. Menutup pembelajaran dengan berdo'a sesuai dengan agama dan keyakinan masing-masing.

\section{Observasi dan Evaluasi}

Peneliti mengamati jalannya pembelajaran dari awal hingga akhir. Dalam penelitian ini digunakan lembar pengamatan yang telah disiapkan sebelumnya. Tindakan yang dilakukan pada tahap observasi aktivitas peserta didik:

1. Aktivitas peserta didik pada siklus II. Pada kegiatan awal sudah mengalami peningkatan yang sangat baik mulai dari kondisi kelas yang terlihat sudah teratur dan tertib.

2. Peserta didik sudah mulai memperhatikan penjelasan materi dan penggunaan model pembelajaran discovery learning.

3. Berdasarkan hasil observasi, aktivitas peserta didik mencapai kriteria sangat baik. Aktivitas Peserta Didik pada siklus II dalam pembelajaran Akuntansi dengan menggunakan model pembelajaran Discovery Learning sudah mengalami peningkatan. Pada tahap ini siklus 1 sebesar $60 \%$ dan siklus II sebesar 92,3\% atau kategori sangat baik. Maka dapat disimpulkan bahwa aktivitas Peserta Didik meningkat. Sehingga termasuk dalam kategori baik dan sesuai dengan indikator keberhasilan.

\section{Analisis dan Refleksi}

Berdasarkan hasil observasi siklus II yang telah dilakukan dapat dilihat bahwa penerapan model pembelajaran discovery learning dapat meningkatkan hasil belajar peserta didik pada mata pelajaran Akuntansi perusahaan dagang. Peserta didik sudah memahami mengenai bagaimana penerapan model pembelajaran ini karena peserta didik mulai terbiasa dengan model pembelajaran yang digunakan. Hal ini menyebabkan pelaksanaan kegiatan belajar mengajar dengan menggunakan model pembelajaran discovery learning menjadi lebih efektif. Nilai Ketuntasan Belajar Minimal (KKM) peserta didik kelas XI Akuntasi pada siklus II mengalami peningkatan sebanyak 45 peserta didik dinyatakan sesuai dengan KKM. Dan hasil refleksi tersebut dapat diketahui bahwa penerapan model pembelajaran tipe discovery learning pada 
siklus II yaitu aktivitas peserta didik mencapai kriteria baik atau 96,9\% dinilai telah berhasil dan dianggap memuaskan sehingga tidak melanjutkan lagi ke siklus berikutnya.

Penerapan model pembelajaran discovery learning ini merupakan tindakan kelas yang bertujuan untuk meningkatkan hasil belajar Akuntansi peserta didik. Penelitian dengan menerapkan dua siklus pembelajaran dengan model yang sama pada setiap siklus, yaitu dengan menggunakan model pembelajaran discovery larning. Setiap siklus yang diterapkan pada proses pembelajaran mampu meningkatkan hasil belajar peserta didik. Peningkatan hasil belajar peserta didik dapat dilihat pada diagram berikut:

\begin{tabular}{ccccccc}
\hline Kriteria & \multicolumn{3}{c}{ Jumlah siswa } & \multicolumn{3}{c}{ Prosentase } \\
& Pra & Sikl & Sikl & Pra & Sikl & Sik \\
& sikl & us & us II & siklus & us & lus \\
& us & I & & & I & II \\
\hline Tuntas & 6 & 30 & 45 & 13,3 & 66,7 & 100 \\
Tdk & 39 & 15 & 0 & 86,7 & 33,3 & 0 \\
tuntas & & & & & & \\
\hline
\end{tabular}

Sumber : Data primer yang diolah 2017

Berdasarkan data yang diperoleh peneliti, terlihat bahwa nilai ulangan harian peserta didik sebelum penerapan model pembelajaran discovery learning terdapat 6 (enam) peserta didik yang hanya mencapai nilai ketuntasan belajar. Hal ini menunjukan bahwa masih banyak peserta didik yang belum mencapai nilai KKM yaitu 75 yang merupakan nilai batas tuntas keberhasilan peserta didik. Masih rendahnya nilai peserta didik disebabkan karena peserta didik belum sepenuhnya memahami materi yang diberikan oleh guru dan peserta didik kurang antusias dalam kegiatan belajar mengajar.

Penyajian materi dengan menggunakan model pembelajaran discovery learning dapat meningkatkan hasil belajar peserta didik. Hal ini terbukti pada siklus 1 nilai tes peserta didik yang mendapat nilai KKM berjumlah 30 orang atau $66,7 \%$. Terjadi peningkatan pada siklus II sebanyak 45 peserta didik yang mendapat nilai KKM atau 100\% dibanding sebelum penerapan discovery learning. Hal ini menunjukan peserta didik lebih memahami materi yang diberikan oleh guru dengan adanya penerapan model pembelajaran discovery learning. Pada siklus II ini ulangan harian peserta didik sebanyak 45 peserta didik atau $100 \%$. Terjadi peningkatan nilai ketuntasan belajar dari siklus I ke siklus II sebesar $33.3 \%$ (siklus I 86,7\% dan siklus II 100\%). Dibanding dengan sebelum penerapan model pembelajaran discovery learning, nilai ketuntasan belajar peserta didik pada siklus II mengalami peningkatan angka sebesar $86,7 \%$ (sebelum penerapan $13.3 \%$ dan siklus II 100\%).

Berdasarkan data siklus I dan siklus II diperoleh hasil belajar yang selalu 
mengalami peningkatan. Model pembelajaran discovery learning berdampak positif terhadap kegiatan pembelajaran Akuntansi. Hal ini terbukti pada peningkatan peran serta peserta didik pada pembelajaran dan hasil belajar peserta didik. Temuan yang muncul selama kegiatan belajar mengajar antara lain sebagai berikut :

1. Kegiatan belajar mengajar di kelas di dominasi dengan kegiatan memperhatikan penjelasan guru, mengerjakan tugas, belajar tim/ diskusi, tanya jawab dan menjawab soal-soal.

2. Pada siklus II antusiasme peserta didik dalam mengikuti pelajaran terus mengalami peningkatan. Hal tersebut dapat dilihat dengan adanya peserta didik yang bertanya kepada guru selama proses pembelajaran maupun selama diskusi dengan kelompoknya.

3. Adanya keleluasaan strategi bagi guru untuk menyajikan materi karena penerapan model pembelajaran discovery learning bersifat fleksibel.

Hal ini memungkinkan strategi penyajian materi guru bervariasi. Terdapat kesempatan belajar sendiri dan diskusi kelompok.

4. Kegiatan belajar mengajar yang menerapkan model pembelajaran discovery learning dapat meningkatkan pencapaian hasil belajar. Hasil belajar tersebut dinyatakan tuntas karena secara umum pencapaian hasil belajar peserta didik berada diatas standar batas tuntas yaitu 75. Hal ini menunjukan bahwa secara umum peserta didik telah memahami materi yang disajikan dengan baik melalui proses pembelajaran dengan menggunakan model pembelajaran discovery learning.

Keberhasilan pembelajaran akuntansi dengan menggunakan model discovery learning dapat dilihat dari indikatorindikator keberhasilan sebagai berikut:

1. Peserta didik sangat menikmati pembelajaran menggunakan model discovery learning.

2. Peserta didik terlihat antusias dan bersemangat selama kegiatan belajar berlangsung.

3. Peserta didik menjadi lebih berani dalam mengungkapkan ide dan gagasannya di depan kelas.

\section{KESIMPULAN DAN SARAN}

Berdasarkan hasil penelitian dan pembahasan yang telah diuraikan sebelumnya, dapat disimpulkan bahwa :

1. Model pembelajaran discovery learning dalam meningkatkan hasil belajar peserta didik pada mata pelajaran Akuntansi di kelas XI 
Akuntansi SMK Al-Insan. Pada siklus

1 sebesar $66.7 \%$, dan di siklus II sebesar $100 \%$. Artinya dengan penerapan discovery learning di siklus 1 dan siklus II mengalami peningkatan dan dapat dikatakan pembelajaran dengan model discovery learning berhasil.

2. Aktivitas belajar peserta didik dengan menggunakan model pembelajaran discovery learning dapat meningkatkan keaktifan belajar peserta didik pada mata pelajaran akuntansi di kelas XI SMK Al-Insan yaitu siklus 1 sebesar $60 \%$ dan siklus II sebesar $96,9 \%$ atau kategori sangat baik dan dikatakan berhasil.

Berdasarkan hasil kesimpulan maka peniliti mengajukan saran-saran sebagi berikut:

1. Bagi sekolah

Lebih meningkatkan tanggung jawab guru-guru mata pelajaran untuk mengikuti pelatihan atau seminar berhubungan dengan model dan metode pembelajaran inovatif.

2. Bagi Guru

Hendaknya guru selalu meningkatkan kemampuannya dalam mengembangkan dan menyampaikan maeri serta dalam mengelola kelas dengan menerapkan pembelajaran inovatif, sehingga proses dan hasil pembelajaran dapat terus meningkat seiring dengan peningkatan kemampuan yang dimilikinya, kerjasama guru dan Peserta Didik selama proses pembelajaran harus diperhatikan sehingga suasana pembelajaran menjadi lebih kondusif dan Peserta Didik dapat lebih mudah memahami materi pembelajaran.

3. Bagi peneliti lain

Hendaknya termotivasi untuk melengkapi penelitian ini dengan menggunakan pendekatan lain untuk meningkatkan hasil belajar Peserta Didik khususnya pada mata pelajaran Akuntansi.

\section{DAFTAR PUSTAKA}

Arikunto, Suharsimi. (2013). Prosedur Penelitian Suatu Pendekatan Praktik. Jakarta: Rineka Cipta.

Darmadi, Hamid.(2015). Desain dan Implementasi Penelitian Tindakan Kelas. Bandung: Alfabeta.

Huda, Miftahul. (2014). Model-model Pengajaran dan Pembelajaran. Yogyakarta: Pustaka Belajar.

Jusup, Al. Haryono. (2011). Dasar-dasar akuntansi. Yogyakarta: Sekolah Tinggi Ilmu Ekonomi YKPN.

Kompri. (2015). Motivasi Pembelajaran Perspektif Guru dan Peserta Didik. Bandung : PT Remaja Rosdakarya. 
Oktaviani, Titin. Penerapan Discovery Learning pada mata pelajaran akuntansi yang meningkatkan motivasi belajar Peserta Didik akuntansi keuangan. [online]. tersedia: library.um.ac.id. (02 April 2017)

Purwanto, Ngalim (2014). Psikologi Pendidikan. bandung: PT Remaja Rosdakarya

Rusman. (2011). Model-model Pembelajaran Mengembangkan Profesionalisme Guru. Jakarta : PT Rajagrafindo Persada.

Sardiman, A.M. (2014). Interaksi dan Motivasi Belajar-Mengajar. Jakarta: Rajagrafindo Persada.

Sudrajat, Akhmad. (2008). Teori- teori motivasi. [Online]. Tersedia: http://akhmadsudrajat.wordpress.co m/2008/02/06/teori-teori-motivasi/. (02 April 2017).

Supriyono, Agus. (2010). Kooperatif Learning. Surabaya: Pustaka Belajar.

Swarsini. Penerapan model pembelajaran Discovery Learning pada Pembelajaran isicerpen. [Online]. Tersedia:http://kompasiana.com. (02 April 2017).

Tn. (2017). Pengertian Belajar dan Hasil Belajar. [online]. Tersedia: http://duniabaca.com. (10 maret 2017).

Trianto. (2009). Mendesain Model Pembelajaran Inovatif Progresif. Kencana: Prenada Media Group. 